\title{
Five Pragmatic Reasons for a Dialogue with and Between Member States on Free Movement and Voting Rights
}

\author{
Kees Groenendijk
}

\begin{abstract}
My first article on political rights of non-citizens immigrants was written together with my late colleague Bert Swart in 1978 for a journal in Rome. Since then my ideas and publications on this issue were guided by three principles: (a) no taxation without representation, (b) the longer an immigrant is resident in a country, the harder it is to justify his exclusion from political rights only on the basis of his nationality, and (c) once voting rights have been granted to non-citizens for municipal elections there are no serious principled arguments against extension to parliamentary elections. The second principle qualifies the first principle. Tourists and seasonal workers pay VAT, but that does not necessarily qualify them for voting rights. They should, however, have at least some other political rights, such as the right to demonstrate or the right to strike.
\end{abstract}

This being said, I do not support the campaign for extending voting rights of EU nationals to national elections in the member state of residence. Five pragmatic arguments in my view outweigh the three principles mentioned above.

(1) I sincerely doubt whether being unable to vote in parliamentary elections in the 'host' member state in real life is a barrier to free movement. Of course, it may be construed as a legal obstacle to free movement. But did many Union citizens decide not to use their right to migrate to another member state or to return permanently to the member state of their nationality, only because they wanted to vote in parliamentary elections in that state? Of course, the unequal treatment has to be justified. And yes, there is the problem of who belongs to the demos or the people(s) of the member state(s). The German Bundesverfassungsgericht in 1989 gave the most restrictive definition of people: only nationals of the country. The Court of Justice in Eman \& Sevinger stressed that the definitions of the concept 'peoples' vary considerably between member states ${ }^{1}$. I suggest that using the right to free

1 Judgment of 12.9.2006, C-300/04, point 44.

(C) The Author(s) 2019 
movement brings certain advantages and certain disadvantages. Not having a guarantee that you can vote in national elections in the other member state unless you acquire its nationality is one of the disadvantages. Empirical data indicate that the participation of EU migrants in the municipal elections in the 'host' member state is relatively low and that a considerable part of EU migrants hide their migration to another member state from authorities of the member state of their nationality. Moreover, 23 of the 28 Member States allow their nationals living abroad to vote in parliamentary elections. Cyprus, Denmark, Greece, Ireland and Malta appear to be the exceptions to the rule.

(2) Current Union law is clear. Both the TFEU and the Charter guarantee participation of EU migrants only for the EP elections and the municipal elections in the 'host' member state. The right to participate in political parties is only guaranteed at 'Union level', not at national level. This was a clear choice of member states during the negotiations on those treaties. The legislator considered that voting at the national level was not within the scope of the Treaty as stipulated in Article 18 TFEU. Only very weighty reason could justify an advice to the Court of Justice to overrule that clear choice of the legislator.

(3) The national legislation of member states on the voting rights of noncitizens and on the right of nationals abroad to vote in the parliamentary elections at home varies a lot. The differences are due to historical, political or other reasons. It is unwise to disregard those differences. The TFEU specifies that the Union shall respect cultural diversity. Differences in political culture are part of that diversity. I would plea to respect this diversity and to learn from the hot political debates, often going on already for decades on the extension of voting rights to long-term resident third-country nationals (also human beings) in Belgium, France, Germany, Italy and Spain. There appears to be a difference in approach to this issue between the Southern and the Northern member states. I would expect that in 'new' member states there could be more sympathy for the 'restrictive' Southern approach than for the more 'open' Northern approach. In several member states the debate on extending voting rights to non-citizens or extension of that right to parliamentary elections has been explicitly linked to facilitation of naturalisation of immigrants, e.g. in Belgium, Germany and the Netherlands.

(4) Granting voting rights for elections on the national level will require either amending the TFEU or using the procedure of Article 25 TFEU. In both cases unanimity of all member states is required. Moreover, in many member states it would require amending the constitution and thus broad political consensus. That consensus simply is not available at present in most member states on this issue. The constitutional amendments necessary to introduce voting rights for nationals of other member states in municipal 
elections were agreed because this issue was one minor point in a large package of changes contained in the Maastricht Treaty. Presenting the extension of voting rights to the national level as an isolated issue to be realised by binding Union law probably will create a lot of opposition and negative publicity for the Union generally.

(5) This proposal will certainly raise the issue of extending voting rights to the national level for long-term resident third-country nationals. Why would a Polish or Portuguese national be allowed to participate in national elections after ten weeks or months of residence in France and a Swiss or a Turkish national be excluded even after ten years of lawful residence in that country?

My first conclusion is: Do not raise this issue in isolation but together with other relevant issues concerning political rights of EU migrants, such as voting rights in national elections for expatriates living in another member state, the right of Union citizens to be a member of or establish a political party in the member state where he lives and the possibility of facilitated naturalisation after having acquired the permanent resident right in another member state (after a minimum of five years of residence).

My second conclusion is: Do not propose binding Union law on this issue or try to make the Court of Justice impose a binding solution for this problem. Rather apply the open method of coordination by starting a structured dialogue with and between member states, possibly combined with the issue of the limits set by free movement law to nationality legislation of member states. We may learn from the experience of the Nordic Union in dealing with the issue of extending voting rights to non-citizen residents, both of the Nordic countries and other countries, during the 1970s and 1980s by structured discussions rather than imposing a common rule from above. With this in mind I would support the fifth option in David Owen's contribution to this debate.

Open Access This chapter is licensed under the terms of the Creative Commons Attribution 4.0 International License (http://creativecommons.org/licenses/by/4.0/), which permits use, sharing, adaptation, distribution and reproduction in any medium or format, as long as you give appropriate credit to the original author(s) and the source, provide a link to the Creative Commons license and indicate if changes were made.

The images or other third party material in this chapter are included in the chapter's Creative Commons license, unless indicated otherwise in a credit line to the material. If material is not included in the chapter's Creative Commons license and your intended use is not permitted by statutory regulation or exceeds the permitted use, you will need to obtain permission directly from the copyright holder. 